\title{
PHILOSOPHY
}

\author{
Nikolsky S.A.
}

\section{Lev Tolstoy: a Russian view of the world and man in it}

\begin{abstract}
The subject of the article is to analyze the anthropological theme in the works of Russian writer Lev Tolstoy and give a characteristic of the Russian view of the world. Lev Tolstoy's works give a researcher a unique opportunity to have an idea about Russian worldview. An artist of genius, tireless worker and searcher for the meaning of life, the count-mouzhik left to future generations innumerable richness of observations, thoughts, artistic topics and images. Due to their depth and versatility they have long become and continue to be a subject of philosophical analysis. The article discusses a number of important meanings and values of Russian worldview that Tolstoy examined. First of all, in is the meaning (to be more precise - search for the meaning) of that which crowns human life. The theme of death and Russian people attitude to it was studied by the writer throughout his whole creative life. The author uses the method of hermeneutic analysis of the Russian writer's texts. Secular and theological thought referring to evaluation of the fear of death has been compared. The article's novelty is in looking for that which can oppose death. Having discovered for himself that the fear of death can be overcome through love as the fullest manifestation of God, Tolstoy turned to its analysis and then to consideration of the other side of this human feeling, devoting a number of great philosophical and artistic works to examination of passion. Sin and repentance, crime and punishment in human and social life, moral and legal justice are another worldview component of Tolstoy's creative work. The thinker's creative search has not been completed. But the very process is that most valuable heritage that he left to the reflecting descendants.

Keywords: literature, philosophy, fear, death, life, worldview, crime, repentance, law, justice.
\end{abstract}

$\mathrm{T}$ he centenary of the death of Leo Nikolaevich Tolstoy (November 2010) is one more occasion for taking a careful look at the works of one of the greatest Russian thinkers of the second half of the nineteenth-early twentieth centuries. In his view, there is still unstudied fundamental content pertaining to his world outlook that answers a need in contemporary Russian society.

\section{From the autobiographical trilogy to Sevastopol Sketches}

The start of the formation of Leo Nikolaevich Tolstoy's systematic world outlook can be dated to 1851, when he set himself the task of writing the story of his childhood. The trilogy mostly depicts the life of the St. Petersburg gentry, but through the unclouded eyes of a child unambiguously conveys the clash between the natural and the social.

Nature, as a realm of being that is independent of man, substantially determines the atmosphere of the living world in the trilogy above all because it is a manifestation of the divine, an absolute moral measure. In Tolstoy, the world vision of the entire Russian people (peasantry) in its "swarm" life ${ }^{1}$ is in harmony with the natural. And the unmediated perception of a child gives special salience to the concepts that are most important for an understanding of the Russian world outlook. Such fundamental categories as nature, the people, life, and death will be present - inescapably but organically and without schematism - in Tolstoy's works. He will be concerned with reality itself and not ideology: many have noted this trait. Thus, N.N. Strakhov wrote that the literary art of Tolstoy cannot exist separately from realistically conveyed "profound thoughts and profound feelings"2.

It is especially important to notice this because the chosen focus of Tolstoy in the first part of the trilogy is the process by which a young child discovers the world for the first time and grows up as he experiences and makes sense of the world and of himself as part of this world.

In the story, Nicky Irten'ev inquires "whether the world is good and whether it [the world] loves him

\footnotetext{
1 By using the term "swarm" to describe the life of the Russian peasantry, the author points to a specific collective (swarm) behavior that was exhibited by Russian peasants of that time. - Ed.

2 Strakhov 2003, p. 309.
} 


\section{Philosophy}

[Nicky]." He also describes his sensations regarding "something like first love." And from the first lines of Childhood the mind of the little hero is troubled by the image of death.

The narrative, as we recall, starts with Nicky's awakening with the contrived thought of his mother's death and with the feeling arising in its wake that the world is out of joint. Passing by what N.G. Chernyshevskii called the "dialectic of the soul" in the trilogy and is connected with the discovery of deep psychological analysis in the prose, let us look at this collision as an expression of characteristic features of the Russian world outlook.

A child, by his very nature, is sure of a fundamental harmony in the world and tries to oppose destruction and death. Fear in the face of death and an instinctual aversion to it arise in Nicky during a wake and start with the cry of a peasant child: "On a stool beside the coffin stood apeasant woman, struggling to keep hold of a little girl in her arms. Trying to ward off the sight with waving hands, throwing back a frightened little face, wide-open eyes fixed on the face of the deceased, the little girl was wailing in a terrible, frantic voice. I shrieked in a voice that, I think, was even more horrible than the voice that had startled me and ran out of the room" ${ }^{3}$. The first encounter of the living with death is an experience of total vulnerability and horror. This is how Tolstoy begins his discourse about death.

The child's mind assimilates new meanings not only in his personal collision with reality but also through interaction with the popular mind, as though seeking its advice. And it is precisely the popular mind that shows Nicky the loftiest examples of a natural existence in harmony with the world. The popular mind revealed itself to the young hero in the personality and fate of his nanny, Natalia Savishna. In general, the narrator is struck by people's intrinsic ability to become accustomed to the calm and routine performance of the most onerous obligations in a situation of the greatest spiritual and moral tension. Later Tolstoy will recall this in describing the defense of Sevastopol and the struggle against Napoleon, when he will embody the faces of toilers of war in the images of Russian soldiers. After the death of his mother, Natalia Savishna talked with Nicky every day, and her quiet tears and tranquil, pious words brought him comfort and relief. And through her own death she gave Nicky his last lesson, bearing suffering with truly Christian patience and humility. His nanny,

\footnotetext{
3 Tolstoi 1978, vol. 1, p. 99.
}

Tolstoy remarks, "did not need to fear death because she died with unshakable faith and having fulfilled the law of the Gospel. Her whole life was pure, unselfish love and self-denial. ...She accomplished the best and greatest thing in this life - she died without regret or fear" 4 . Tolstoy learned how to do that throughout his life.

Tolstoy's first works already display the series of meanings and values that will determine the philosophical and ethical content of his subsequent workswhat will take shape in War and Peace as the socalled popular thought, formed not in the bosom of reason but in the depths of some profound feeling. It seems that this "thought" comes from that unreasoning popular essence that unites the common person with the whole universe, with nature. The capacity for such instinctual union with the world, Tolstoy supposes, is intrinsic not only to the man of the people - the peasant, above all - but to any human being, and ineluctably manifests itself within him as soon as he casts off false social conventions. What else but this most important matter, for instance, preoccupies Tolstoy's favorite character, Pierre Bezukhov? Or Andrei Bolkonskii when he lies under the sky of Austerlitz after rejecting the whole customary hierarchy of values? What else but union with nature (and God) does Konstantin Levin seek in his business activity?

One of the means to such union in Tolstoy is hunting. Hunting - a pastime so beloved of the Russian people and the theme of much rapturous writing by Turgenev - naturally releases instincts in man that acquire monstrous destructive power at times of war. Hunting lays bare the deep-rooted kinship of people who stand on different rungs of the social hierarchy, and between all of them and nature, the world of God's creation. The well-known philosopher Mikhail Lifshits ${ }^{5}$ has devoted much attention to analyzing hunting episodes in Tolstoy, in order to show how the "miracle of art" through "Tolstoy's peasant voice" is connected directly with his philosophical and social ideas. "Hunting is a noble vestige of those times when the simple life activity of the animal merged with the first steps of social labor. It is remarkable that as civilization develops hunting does not disappear from man's field of vision: it becomes more freed from its

\footnotetext{
Ibid., p. 107.

Mikhail Aleksandrovich Lifshits (1905-1983) was an original Soviet philosopher of art, who undertook an analysis and development of esthetics from a fundamentally Marxist perspective. - Ed.
} 


\section{Nikolsky S.A.}

purely utilitarian purpose and acquires a certain autonomy as a useful trial of strength"6.

In Tolstoy's hunting episodes, the intermediary between the (largely artificial) world of gentry life and the world of nature turns out to be the same peasant [muzhik], to whom the lord of the manor [barin] must listen. In War and Peace, Lifshits notes, "in the whole scene of the hunt there are, in essence, only two real men: these are the old wolf, captured after a desperate struggle, and the master of hounds, Danila. ...Like any serious test, hunting entails its own kind of «Hamburg reckoning» ${ }^{7}$. It overturns social relations, and in a single instant everything that pulls upward or downward, all ranks and values change places. The game becomes the real world, while other things - titles, wealth, connections, conditions - become somehow unreal"8.

Another character who tests the truth of his being by means of the hunt (that is, man's dialogue with the natural) is Dmitri Olenin in the story Cossacks [Kazaki] (1863). Noting the influence on Tolstoy of

Rousseau and Stern, M.M. Bakhtin, in particular, sees in this novel a clearly marked opposition between nature and culture. "Inalienable nature is Daddy Eroshka; the spirit is Olenin. But Olenin is the bearer of a complicated cultural principle: contemplating the natural life of the Cossacks, he experiences this antithesis within himself. From his point of view, it is bad for a person to be psychologically predisposed toward self-observation... Conscience, whose prompting is reflection, ...destroys a person's natural wholeness... To the self-reflexing Olenin are counterposed the Cossacks. The Cossacks are sinless because they live a natural life" ${ }^{\prime \prime}$. Bakhtin, in essence, notes here one of the chief categories of Tolstoy's world outlook - the deep and beneficial link between man and nature.

Dmitri Olenin is one of the first voluntary exiles in Tolstoy's prose, who continued the tradition of Push-

\footnotetext{
6 Lifshits 1979, p. 181. Hunting, Lifshits argues, is not an incidental theme in nineteenth-century Russian literature. It entered literature together with the focus on nature and peasant life as fundamental supports of the national world outlook. In Turgenev, for example, the nobleman-hunter in his Notes of a Hunter [Zapiski okhotnika] is a wanderer away from his home and country estate, and free of obligations to them. Those who happen to join him in his free hunter's life, for a certain time or forever, are torn away from the soil and neglect their age-old occupations.

7 Revealing a real, and not official, status of individuals within the system of the social hierarchy. - Ed.

8 Lifshits 1979, p. 183.

$9 \quad$ Bakhtin 2000, p. 239.
}

kin's Aleko ${ }^{10}$. He is fettered by no chains, physical or moral; he can do anything and needs nothing; nothing binds him. He has neither family nor fatherland, neither faith nor need. Everything changes when Olenin ends up in the Caucasus.

The romantic image of the war - filled with images of wild Arabian horses, Circassian women, mountains, precipices, terrifying torrents, and dangers - vanishes from his mind. The absence of civilization and the crudity of the local inhabitants produce an illusion of freedom, and at first the hero relishes this new feeling. But in this world he is perceived as foreign. The only person who shows goodwill toward him, "Daddy Eroshka," is "inalienable nature," as Bakhtin puts it. He even looks like some sort of nature demon reminiscent of Pan: of enormous height, with a broad beard white as snow and broad shoulders and chest. The Cossack presents to Olenin a straightforward philosophy of an epic past, a golden age; against this background, the present day seems unnatural and dwarfish. "Nowadays such Cossacks do not exist. It feels bad to look," says Eroshka. He recognizes neither religious nor legal norms and laws. "But, in my opinion, everything is one. God made everything for man to enjoy. There is no sin in that. Take the wild beast as your example, if you like. It lives both in the Tatar reeds and in ours. Wherever it goes, there is its home. It gobbles up what God sends. But our people say that for this we shall lick hot pans. I think that it's all wrong. ...When you croak, the grass will grow over your grave, that's all"11.

Here Eroshka touches on the most important theme - death. And immediately other works of Tolstoy come to mind in this connection. Prior to Cossacks, the writer completed two short stories based on his personal experience. These are Lucerne [Liutsern], which conveys his impressions of an execution by guillotine in Paris, and Three Deaths [Tri smerti], whose plot is explained in detail by Tolstoy himself in a letter to his aunt: "My idea was: three creatures have died - a noblewoman, a peasant, and a tree. The noblewoman is vile and pitiable because she lied her whole life long and lies in the face of death. ...The peasant dies a tranquil death, precisely because he is not a Christian. He has another religion, although by habit he performed Christian rites; his religion

10 The main character of The Gypsies (1824), a narrative poem by Alexander Ser-geevich Pushkin, Aleko represented the "traditional Russian sufferer detached from the people," who wanders in search of his universal ideals and hoping "to find refuge in the bosom of nature from the confused and incongruous [social] life." (F. Dostoevsky). - Ed.

11 Tolstoy 1978 , vol. 3, p. 221. 


\section{Philosophy}

is nature, with which he lived. He cut down trees, sowed and reaped rye, killed rams, and rams were born for him, and children were born, and old people died, and he firmly knows this law from which he never hid his face, as the noblewoman did, and simply looked it straight in the eyes....The tree dies a tranquil, honest, and beautiful death. Beautiful because it does not lie, does not break, does not fear, and does not pity"12.

Dmitri Olenin is the first character in Tolstoy's prose who thinks about departing into an almost natural existence. He is struck by the same idea that in various forms will later disturb Bezukhov and Levin and Nekhliudov - the idea of breaking away from his social estate and crossing into the realm of natural being. "Why don't I do this? What on earth am I waiting for?" - Olenin asks himself, but is unable to extricate himself from the trap of reflection. He does not manage to become his own man among the Cossacks. The verdict against him is pronounced by the Cossack woman Mariana: "Get lost, you creep!" And when he leaves the village, Mariana, whom he loved, and Eroshka do not even turn their heads: the barrier proves insuperable, the departure into a natural existence does not take place.

From a certain point of view, the whole life of Leo Tolstoy, from his youth to advanced old age, is either a flight from his social milieu or the intention to make such a flight. By his own admission, he goes to the Caucasus in order to escape debts and habits, but perhaps mainly because after leaving the university and experiencing the collapse of his plans in 1847 he simply did not know where to go or what to do. Judging from Cossacks, the Caucasus gave Tolstoy, first, an opportunity to grow closer to the people - the soldiers and the Cossacks - and, second, a chance to test himself under difficult circumstances. But his flight was not confined to the Caucasus. In November 1854 Tolstoy is already in Sevastopol, a participant in the war against Turkey and its allies. Soon thereafter, in 1855, sevastopol sketches appears. Despite the documentary character of this work, its artistic focus is again the Russian world outlook, illuminated by Tolstoy from new angles.

Here, in the context of the phenomenon under consideration, Tolstoy for the first time poses the problem of change in value priorities. In saying this, I have

12 Ibid., vol. 3, p. 455. Tolstoy himself finally resolves the struggle against the fear of death by departing from his habitual but now alien life environment. And this departure turns out to be a departure into death. in mind the following. Each social stratum, possessing and living within its own culture, recognizes and rationalizes it through certain hierarchically ordered meanings and values. But then there occurs a terrible event war - and each of these meanings and values, as well as the hierarchy that orders them, are put to the test. And their content changes, and the hierarchy is ordered anew: what was vitally important for the parents means little to their children.

Tolstoy's conception of war in Sevastopol Sketches differs considerably from the conception that we find in Cossacks or, for instance, in the story The Raid [Nabeg]. In Cossacks, Tolstoy's character merely touches lightly on war; he has yet to descend into its pitiless and alldevouring maw. War is waged, as it were, "part time" - that is, only when the characters themselves choose to wage it, often in the hope of obtaining awards, ranks, or horses. Here, for example, is a picture from The Raid. The commander of a Russian detachment observes the battlefield: '"What a splendid sight!' - exclaimed the general, lightly prancing in the English style on his black slim-legged horse.

«Charming!» - the major replied gutturally. «... Truly a delight to fight in such a splendid country. «And especially in good company, added the general with a pleasant smile» ${ }^{13}$.

Between the Caucasian and the Crimean war, as Tolstoy depicts them, there is an enormous difference. While in the Caucasus Russia fights people whom it considers its subjects and when it so wishes, in the Crimean war it faces a foreign enemy. In the Caucasus, war is an angel of death who flies past only from time to time, like the chance pistol shot of the Chechen prisoner at the young Cossack. War in the Crimea is an invisible killer in a neighboring trench whose eyes remain open day and night.

However, not only in the Caucasus but also in the Crimea Tolstoy draws an explicit distinction between "the gentry's war" and "the people's war." In the first parts of the cycle - Sevastopol in December [Sevastopol' $\mathrm{v}$ dekabre mesiatse] and Sevastopol in May [Sevastopol' v mae] - the theme of "gentlemen at war" is depicted with a very palpable sense of the author's contempt. Thus, there is a detailed description of one of the officers' feasts at which good wine flows freely and Gypsy songs are sung to the accompaniment of a piano. To a lieutenant colonel's remark that it is impossible to fight without conveniences, Prince Gal'tsin replies: “I don't understand and, I admit, I can't believe that lice-ridden people wearing muddy underwear and with unwashed

13 Tolstoi 1978, vol. 2, p. 25. 


\section{Nikolsky S.A.}

hands could be brave. So, you know, this splendid bravery of the nobleman cannot be"14.

The war sketches encompass a broad range of problems and themes - war from the human and the natural point of view, the emotional state of people at war, the greatness of the Russian peasant soldier who calmly, confidently, and without praise defends his homeland. It is in vain, Tolstoy remarks, that we would look here for the display of any special heroism. There is nothing of this. There are everyday people engaged in an everyday task. But this must not lead us to doubt the heroism of the city's defenders: the author convinces us of this by showing us pictures of the steadfastness of the wounded despite the cruelest suffering. The culmination of the trials of human nature in the first of the Sevastopol sketches is the fourth bastion. And again Tolstoy shows two different perspectives on this "terrible bastion": that of those who have not been there and that of those who fight there. The former will say that the fourth bastion is a true grave for all who end up there; the latter say only whether it is dry or muddy, warm or cold in the trench.

Immersing the reader in the prose of military life, Tolstoy leads him along a path that is full of mud. Virtually every part of the text contains this word. Mud mixed with blood is, indeed, the prosaic image of war, and it is much harder to confront this image than it is to perform romantic acts of heroism. In general, mud - in fact, earth mixed with water (both the earth that feeds us and the earth as a source of minerals) - plays the role of an accompanying element in Tolstoy's descriptions of the transition from life to death that may occur at each and any instant. Let us recall that the same kind of "mud" accompanies the path of the noblewoman dying of consumption in Three Deaths. Especially symbolic is the scene in which a carriage bearing the dying woman stands at one of the stops right in the middle of a muddy patch, and the noblewoman, unlike those accompanying her, lacks the strength to drag herself out of the mud onto dry ground. This is a forewarning to all who are dying that the earth is already waiting to receive them in its soft bowels.

Work as toil - here is Tolstoy's definition of this phenomenon, a definition that has become fundamental to twentieth-century Russian war prose. So the image of the soldier as an inconspicuous toiler of war will occupy a central place in Tolstoy's plot. And who more adroit than the peasant to perform this toil? "In the girth of these shoulders, in the stoutness of these legs, ...in every calm, firm, unhurried movement we

14 Tolstoi 1978, vol. 2, p. 115. see these chief features that constitute the Russian's strength - simplicity and persistence; but here on each man's face it seems to you that the danger, malice, and suffering of war, besides these chief signs, have also left traces of an awareness of his own worth and of lofty thought and feeling"15.

The truth of the Crimean war is that the hero of Sevastopol is the Russian people defending its land. Social egoism and the falsity of society are at odds with this truth. The writer is deeply disillusioned in the Russian officer corps. While still in Sevastopol, he composes an angry memorandum to the Grand Duke about the state of the Russian armed forces. In it Tolstoy describes the horrifying conditions in which the "oppressed slaves" are placed - soldiers forced to obey "thieves, oppressive mercenaries, and looters" - and the low moral and professional level of the officer corps. He also tells of these things in the second cycle of sevastopol sketches. However, the pretenses of falsehood and vainglory are destroyed as soon as these officers are brought face to face with the stern truth of war.

In sevastopol sketches the "little Napoleons" or "little monsters of cruelty" also make their first appearance in Tolstoy's work - officers who are ready to go into battle this very minute and kill a hundred people for the sake of an extra star on their epaulettes or a one-third salary increment. In the last chapter of the work, Tolstoy reveals his philosophical credo, showing the equality of attackers and defenders in face of the enormities of Nature and Death. "On our bastion and over the French trench white flags are raised, and between them disfigured corpses, without boots and clothed in gray and dark blue, lie in clumps across the blooming valley. Workers remove the corpses and lay them in carts. The horrible heavy smell of dead flesh fills the air."

In the synthesizing part of Sevastopol in August 1855 [Sevastopol' v avguste 1855 goda], the images used to convey the opposition between natural and artificial life are those of Lieutenant Mikhail Kozel'tsov and his brother Vladimir. Mikhail Kozel'tsov is an officer who was first to do all that he considered correct and that he himself wanted, understanding no other choice but to come first or be destroyed. Self-esteem is the source of all his motives. Vladimir Kozel'tsov is one of the first images in Tolstoy of a young man who finds it difficult to master the everyday prose of war. The youth is overcome by a feeling of "lonesomeness and general indifference to his lot." "This awareness of lonesomeness and danger in the face of death ...lay on

15 Tolstoi 1978, vol. 2, p. 106. 


\section{Philosophy}

his heart like a terribly heavy, cold stone. «...Lord! Am I really a coward, a foul, base, and contemptible coward? Am I really unable to die honestly for fatherland and tsar?» Tolstoy's character manages to recover his courage only by appealing to God. The prayer that purifies his soul organically merges into the prayer of the author. "Great Lord! You alone have heard and know the simple but fervent and desperate entreaties of ignorance, confused repentance, and suffering that have ascended to you from this terrible place of death - from the general who a second before was thinking of breakfast and the St. George's Cross around his neck but with fear senses your closeness to the tormented, hungry, and lice-ridden soldier who has fallen to the bare floor of the Nikolaev Battery and beseeches you to give him right there the reward - of which he has an unconscious presentiment - for all his undeserved suffering! No, you have not tired of listening to the entreaties of your children; everywhere you send down a comforting angel to bless their souls with patience, a sense of duty, and the consolation of hope"16.

Again and again, Tolstoy returns to the idea of the unity of mankind in face of the supreme judgment of death, which annuls all bustle, all petty human squabbles. And those of Tolstoy's characters whom he allows to be imbued with this idea demonstrate its healing effect on the human soul.

Death - one of the chief characters in Tolstoy's war prose - does not release its grip on him but continues to agitate his mind. And in this connection I want to recall the story The Snowstorm [Metel'] (1856). With the mastery of a subtle scholar, Tolstoy examines the special characteristics of a "nonmilitary kind" of death and discusses the tricks that enable a person not to slide off the edge between life and death.

A lord of the manor (the narrator) traveling in winter over the steppe has an opportunity - in fact, more than one - to avoid entering the path of an emerging snowstorm: first, when the coachman expresses doubt regarding the success of the journey, and, second, when having already turned back he encounters a troika moving in the direction he needs. His choice to go on sets the bounds of a deliberately initiated game with death.

In a picture that is in equal measure realistic and surrealistic (in the form of a dream), the character immerses himself in a night seance of acquaintance with death. Of the images that visit him, the dominant one is attended by a feeling of helplessness, of inability to intervene in the course of events. The game with

16 Tolstoi 1978, vol. 2, pp. 177-78. death reveals its rules and logic. Thus, participants in this game do not have the right to demonstrate their fear or complain in any way. Another rule is that one is not allowed to ask questions concerning the chief issue - whether one is going to survive. Doing so is not only pointless but also a bad sign. The images of people created by Tolstoy are also remarkable and make their own contribution to understanding the course of this game. The common striving that unites them is to continue performing the task appointed to each person, come what may. Thus, the peasant, swearing and risking his life, throws himself into the impenetrable gloom to catch runaway horses, and another comes to his aid, adapting another horse to this end. The "counselor," who for the time being is not required to perform any task, does not stop telling his tales. The front coachman Ignat does not become dispirited. Let us recall that Tolstoy observes behavior of the same kind - continuing to perform the appointed task, come what may - in the soldiers defending Sevastopol.

In this situation, Tolstoy's character is visited by a rather ominous and even amoral fantasy: "It seemed to me that it would not be bad if toward morning the horses themselves should bring us half-frozen into some remote, unknown village, if some of us should even be frozen completely"17. In the picture that unfolds before us, the images of those who are playing this game for the first time (the narrator) clearly differ from the images of those who have played it before. The "old-timers" - the coachmen - set both the rules of the game and the general optimistic mood. They convey their confidence to the reader and to the traveler who has fallen into such circumstances for the first time in occasionally dropped phrases: "Don't worry: we'll make it!" So they do, and the story reaches its culmination: "We made it, Sir!"

Examining the experience of his development as a child, adolescent, and young man, as well as the personal experience of war as a borderline situation, helped Tolstoy (unlike, for instance, Pushkin, Gogol, or Turge-nev) find a new approach to comprehending the Russian world outlook. The decisive aspects for Tolstoy were the closeness of the Russian mind to nature, its orientation toward the Creator, and its clear view of what really matters most in life and what is of secondary importance. Under the borderline conditions of war and in the proximity of death, Christianity emerges as the deepest foundation of the Russian world outlook. At the same time, even in the early period of his work Tolstoy's conception of the relations between man and

17 Tolstoi 1978, vol. 2, p. 232. 


\section{Nikolsky S.A.}

God leaves no room for the mediating role of the church (as is well known, this was to lead Tolstoy into some conflict with the church).

Having started to discern all these meanings since the first steps of his literary career, in his subsequent works the author of War and peace uncovers with increasing thoroughness the significance of these concepts for the whole structure of Russian self-consciousness. In these works, which analyze essentially existential situations, it is characters from among the people - the peasant in the guise of a hunter or in a soldier's greatcoat, or else the nobleman who has chosen the "simple life" and accepted the people's truth - who appear as the arbiters of good and evil, truth and falsehood, heroism and cowardice.

\section{The novels War and Peace,}

\section{Anna Karenina, and Resurrection}

Passing on to War and Peace, I would like to say, first of all, that Tolstoy's interpretation of the themes of war and peace seems to me broader than a simple demarcation between wartime and peacetime; I see it as connected with the concepts of "death" and "life" and with the boundary that divides them. In Tolstoy, war is not just armed conflict, but also any "nonlife," the threshold of death; in equal measure, unnatural, "artificial" social relations are states of war and often lead to death. The skillfully designed marriage of convenience between Pierre and Helene ends in disintegration; the reveries of Andrei Bolkonskii before Austerlitz, built on false ideals, bring him to the edge of life and death.

The inauthentic, the nonliving mimics the living, tries to adopt its face. On a bet, Dolokhov drinks a bottle of rum while sitting on the windowsill, risking a crash: what a display of vitality, or so it would seem - youth, wildness, daring! But this bravado has no justified goal - it is merely a desire again to raise his status in the eyes of his own circle.

Let us also recall in this connection how Dolokhov cheats at cards with Nikolai Rostov. Dolokhov knows that a loss of 43,000 rubles is almost ruinous for the count's family, which has received him with all cordiality, but cold-bloodedly goes ahead. That Dolokhov is in the service of death or "war" is revealed by Tolstoy himself in his description of what is taking place inside him: "As though bored with daily life, Dolokhov felt the need by means of some sort of strange and mostly cruel act to escape from it"18. "To escape" from life. Into what? Only into death.

18 Tolstoi 1979, p. 56.
Participation by the living ("peace") in what is created and functions by the logic of the dead ("war") does not pass without consequences for the living. Let us recall that Nikolai Rostov, drawn into the card game with Dolokhov and knowing how heavy a blow he will inflict on his father through his loss, nonetheless continues to play. And then, like a zombie, he tells his father of this in light-hearted words and an impudent tone: he has lost and it doesn't matter to whom. And only the meek reaction of Count Ilya Andreevich, as though in the face of death (is this not the embryo of Tolstoy's "nonresistance to evil by force"? - S.N.), makes Nikolai come to himself and return to life with the saving cry: "Papa! Pa-pa! Forgive me!"19. The cry, like the first cry of a newborn baby, is one of Tolstoy's signs for the turning away from death, its retreat in the face of life, the victory of living "peace" over dead "war." (In this connection, let us recall the cry of the little girl, and then of Nicky Irten'ev too, at the sight of the body of the dead mother; here too it is by means of a cry that the living restores itself to life, leaving the zone of dangerous proximity to death.)

Tolstoy describes with special care the technology by which the nonliving (artificial) devours and destroys the living through the example of the seduction of Natasha [Rostova] by Anatol Kuragin. Remarkably, Tolstoy chooses as a background for this an opera performance, depicted in a markedly ironic and estranged manner. Natasha watches the whole proceeding with astonishment and derision; it even seems "savage" to her. Let us note that Tolstoy repeatedly returns to this reaction of the natural and living to the artificial, theatrical, and nonliving: in an artificial world everything takes place as on a stage with painted scenery. By showing Natasha's interaction with Helene and her brother Anatol interspersed with the stage presentation of scenes of life, love, and death, Tolstoy emphasizes the fundamental similarity between the one and the other. In the realm of the artificial, Dolokhov, Helene, and Anatol, as real angels of death, rule the roost. At the same time, like actors on the stage, they pass themselves off as living. They do not find this difficult, because they are beautiful and self-confident, and Natasha involuntarily starts to imitate Helene, smiling at Boris Drubetskoi in the same way as Countess Bezukhov and then sitting in such a pose that Anatol should have a better view of her profile. Gradually she ceases to find the proceeding strange and, on the contrary, derives pleasure from it.

Tolstoy accompanies the appearance of Anatol in Helene's box with the remark: "In the box ...it smelled

19 Ibid., p. 66 


\section{Philosophy}

cold." The nonliving carries with it murderous cold. Anatol, starting to acquire mastery over Natasha, invites her to a masked ball - another situation of imitation and sham. Although Natasha feels that Anatol has "indecent intentions," she lacks the strength to resist. "His closeness, and confidence, and the good-natured tenderness of his smile conquered her. ...With horror she sensed that there was no barrier between him and her" ${ }^{20}$. Natasha confesses to Sonia: "I have no will, he is my master, I am his slave. The play is finished: the nonliving has devoured the living."

The soulless and amoral, which constitute the essence of what Tolstoy calls artificial, are the other-being of death, its real presence in human life, in the nature of each one of us. The nonliving, in its travels through the real world, unavoidably causes the living to perish. Natasha's love for Prince Andrei will perish. Tolstoy defines Natasha's act with Pierre's words as "baseness, stupidity, and cruelty"21. But how and why did it become possible? To this there is no answer. However, this merely strengthens our impression of the irrational strength of the nonliving, the enormous power of death.

An encounter of the nonliving with the living is, as a rule, ruinous for the living. Only when one nonliving being unites with another of the same ilk does tragedy not occur. The limited and rational Vera Rostova and the pettily pragmatic Berg are happy in their marriage. The marriage of convenience between Boris Drubetskoi and Julie is successful. Do-lokhov, who delights in controlling the wills of other people, including Anatol Kuragin, is satisfied with his life. The troika coachman Balaga, who - as the author observes - "loves to topple a carter or knock down a pedestrian as he drives around Moscow," is sincerely devoted to his masters, Anatol Kuragin and Dolokhov, and happy with the fullness of his "nonliving" existence.

In order to describe the condition of Natasha, who has fallen into the paws of the nonliving, Tolstoy introduces the figure of Pierre - an embodiment of the moral principle. His presence enables us to see more clearly what has happened to Natasha. "Natasha felt between herself and him in the highest degree that power of moral barriers whose absence she had felt with Kuragin"22. Thus, moral integrity and a developed moral sense are attributes of life and enable a person successfully to withstand the death principle.

In reflecting upon the war between the living and the dead, Tolstoy continues the tradition of the "dead

\footnotetext{
20 Tolstoi 1979, p. 344.

21 Ibid., p. 375.

22 Ibid., p. 76.
}

and living souls" of the great Gogol, who placed before many generations of Russian thinkers the question of the interaction between the life principle and the death principle in the life of each person and of society. Nevertheless, in Gogol "dead" souls are separated from living ones, for the world of the living is outlined in the notes to the second volume of the poem ${ }^{23}$. In Tolstoy, by contrast, we see a picture that reflects all the complexity of the entanglements of the living with the dead, including within the literary characters themselves. Indeed: is it the life principle or the death principle that comes out on top within Prince Nikolai Bolkonskii in his relations with Princess Maria? And how is it possible for Dolokhov, who embodies everything nonliving, to tenderly love his old mother and crippled sister? There is no eternal peace, but there is a mixed state of "war-peace" as a form of human living.

All the main heroes of Tolstoy's novels run up against the phenomenon of death. But what a difference there is in the attitude taken toward death between those who stand on the side of the nonliving ("war") and those who stand on the side of the living ("peace")! The main character of Eugeny Shvarts's celebrated play Shadow [Ten'] frees himself of his shadow, which has gone out of his control, by means of the words: "Shadow, know your place!" Here too, in the epic novel, we have the persistent feeling that the real heroes are able to say at the decisive moment: "Death, know your place!" - and death retreats.

In what lies the strength of the heroes who are able to pronounce such words? This strength is seen most clearly in the image of Captain Tushin, a soldier who comes from the people. The captain is by no means an organically fearless being, executing the will of an equally heroic high command. Like all living beings, he thinks about and fears his possible death. Tushin is made fearless through selfless performance of the toil of war, complete absorption in the logic of the task at hand. According to Tolstoy, people of this kind are, above all, peasants or lords of the manor who are akin to peasants in spirit. When he depicts his favorite characters from the Rostov family, Tolstoy misses no occasion to emphasize their closeness to the people.

Tolstoy discovers another way of resisting death among the artillery troops on Kurgan Hill, which Pierre visits during the Battle of Borodino. This is when people live and act as a single organism, penetrated - as Tolstoy puts it - by "fervent patriotism." Then an as-

23 Gogol's Dead Souls (1842), though usually regarded as a novel, is subtitled A poem. Gogol called it "an epic poem in prose." - Trans. 


\section{Nikolsky S.A.}

tonishing pattern emerges: the greater the presence of death, as it carries away the defenders one after the other, the more cheerful and lively their conduct. This struggle of life against death reveals one important special characteristic of the living: the brightness of the "fire of life" does not depend directly on the number of people who bear this fire within themselves. On the contrary: the fewer people remain alive, the more brightly burns the fire. The closer death approaches, the greater the responsibility of each man for his deeds, for each may turn out to be the last within whom the fire of life burns.

Tolstoy continues his investigation into the phenomenon of death in the final section of the novel. However, while earlier he has focused mainly on the actual fact of death, on how death - including in its guise of the artificial - acts, now he is more interested in the attitude of his characters toward death. These characters undoubtedly include: the dying Prince Andrei; Pierre, sentenced (he is sure of it) to be shot; the sick Platon Karataev, who knows that death is close; and, finally, Petya Rostov, who dies an instantaneous death. Prince Andrei renounces earthly life to the degree that he ponders the prospect opening up before him, its principle not of earthly but of eternal love. The essence of eternal love - "to love all people," "always to sacrifice oneself for love" - means in ordinary life "to love no one," "not to live this earthly life." And the more he is filled with this "principle of love," the further he departs from life and the more completely he destroys "the terrible barrier that in the absence of love stands between life and death." Especially important are the pages of the novel on which Tolstoy describes the prince's state of mind in his last two days, when there began the final "moral struggle between life and death, in which death was victorious" 24 - a state of mind that Natasha called "that has happened to him." The truth that there are two loves - earthly love as attachment to a particular living person and "eternal love," which is not connected with a living person - does not find a place in Andrei's mind. "'Love? What is love?' he thought. 'Love impedes death. Love is life. Everything that I understand, everything, I understand only because I love. Everything exists only because I love. Everything is connected by love alone. Love is God, and to die means that I, a particle of love, return to the common and eternal source.' He found some consolation in these thoughts. But they were only thoughts. There was something missing in them; something was one-sidedly personal, mental - they lacked obviousness. And there was the same uneasiness and

24 Tolstoi 1979, p. 76. confusion. He fell asleep"25. Let me draw attention here to Tolstoy's remark: "But they were only thoughts." Like any human being, Tolstoy is incapable of unraveling the mystery of eternal love, but he comes right up to the boundary that divides it from earthly love and is aware that a person is incapable in principle of crossing this boundary during his life. Interestingly, it is precisely in the context of these reflections that Tolstoy confirms the solution that he has found to the question of how not to fear death. This solution lies in the striving of a living being toward moral perfection. "With all the strength of his soul, he had always so persistently sought one thing - to be completely good - that he was unable to fear death"26 - says Tolstoy in the words of Pierre.

Alongside life and death as fundamental meanings and values of the Russian world outlook, the values of the people and nature are of equal significance to Tolstoy's views. This is connected, above all, with the image of Pierre Bezukhov, with his striving unreservedly to merge with the people. As we recall, the appearance of Bezukhov at Borodino Field is preceded by Natasha's prayer in the home church of the Razumovskiis and by the public service for the troops on the eve of the battle. Natasha Rostova, who has recently experienced her own "Austerlitz," is also looking for paths of reconciliation with the world around her. To the first words of the priest, "In peace let us pray to the Lord," her soul responds: "In peace - all together, without distinction of social estate, not in enmity but united by brotherly love - we shall pray." This state of Natasha's soul is a reflection of the state of the Russian world on the eve of the war. It is conveyed to Pierre, and in unison with Rostova's home prayer, the common prayer, before the battle rises over Borodino Field. This sets the scale of what is happening to the nation and to the individual. Pierre's world vision in this episode is congruent with the event unfolding before him. And he himself appears commensurate with the dimensions of the heroic epic, as though he were turning into a hero from Russian epics [bogatyr']. And while previously Pierre was the executor of an alien and egoistic will in opposition to the laws of the universe, now he follows higher rules, revealing his powers and abilities.

In his movement around Borodino Field, Pierre is accompanied by the sun. It illuminates down to the tiniest details the panorama of the approaching battle, which now acquires essentially universal dimensions. This historic clash of nations becomes their compre-

25 Ibid., pp. 69-70.

26 Ibid., p. 230. 


\section{Philosophy}

hension of their own essence. Nature, as it were, sympathizes with the Russian world, and therefore guides and supports Pierre at the crucial moment when he grasps the essence of life. The forces of nature and the forces of the Russian people merge together. The soldiers of the Raev Battery and their "world" align themselves with History and Nature. In the faces of these simple people - in essence, peasants - there burns a sunlike, divine fire. Pierre too is pulled toward it as he strives to test its sublime power on himself. "'War is the hardest subordination of a man's freedom to the laws of God....Simplicity is submission to God; there is no getting away from him. And they are simple. They don't talk but act. Speech is silver, but silence is golden. A man can master nothing for so long as he fears death. And all belongs to the man who does not fear it. Were it not for suffering, a man would not know his limits, would not know himself. The hardest thing ....is to be able to unite the meaning of everything in your soul. To unite everything? ...No, not to unite. It is impossible to unite thoughts, but to connect all these thoughts - that's what is needed! Yes, it is necessary to connect, necessary to connect!' - Pierre repeats to himself with inner rapture, feeling that it is precisely and only these words that express what he wants to express and resolve the whole question that is tormenting him"27.

Pierre does not suspect that the chief Word (Logos) of his world vision was not born in abstract talk with his Mason-"benefactor" but came [into existence] from the life of the people. It was the voice of the riding master who awoke Pierre: "We have to get going, it's time to get going, Your Excellency!" ("To connect" [sopriagat] - "to get going" [zapriagat] - this, it seems, is more to the point!) Thus, the meanings that matter to Pierre arise from the peasant masses, from a word or gesture. Having awoken, Pierre rejects the "simple" roots of these meanings. He does not want to see the dirty coaching yard, with a well in the middle by which soldiers are watering horses; he wants to understand what was revealed in his dreams, not suspecting that the answer to his questions lies in the "connection" between the dirty coaching yard and his philosophical and moral quest. And the whole of Pierre's subsequent path is, according to Tolstoy, the simple path of connecting his own life with the life of the people and nature. Tracing how Bezukhov moves through Borodino and beyond, we can see: neither Pierre nor anyone in whom there lives a sense of the whole constituted by the people and nature has any other path but that of

27 Tolstoi 1979, p. 306. subordinating his own private (outer) existence to the (inner) existence of the entire nation.

Trying to comprehend the intent of Tolstoy's epic, we may conclude that its outcome is to establish the goal toward which the Russian world must move. This goal is the familial unity of the nation, resting on a natural foundation that also includes the harmonious combination of the masculine (Pierre) and feminine (Natasha) principles.

The interpretation of the fundamental meanings and values of the Russian world outlook that Tolstoy began in War and peace was continued in the "family" novel Anna Karenina. Comparing the chief themes of the two great works - love and business, life and death (the dead and the living) - I note the following. In a series of key points, Anna Karenina is not simply the work written after War and peace, but the philosophical development and deepening of the latter.

One of the themes thus developed is that of business. Konstantin Levin is a no less significant hero of the novel than Anna Karenina. As has rightly been observed by, for instance, the well-known Tolstoy scholars A. Zverev and V. Tunimanov, "these characters are essentially similar, even though the results of their life odyssey are diametrically different for in both cases the central plot and hub of this odyssey are a crisis in customary values and a craving to live in accordance with the demands of natural moral feeling and not under the power of a generally accepted but false norm" 28 .

Konstantin Levin is Tolstoy's first carefully elaborated program-response to the question of whether "positive affair" is possible in the Russia of his day. For Levin, as for Tolstoy himself, the standard response is peasant laboring. Agrarian activities, which wholly fill a person's life with their intrinsic variety, are possible only in the collective harmonious interaction of many people and in direct contact with nature, and in Russian literature they have always been one of the favorite positive examples of ideally organized human existence. From Fonvizin with his "state entrepreneur" Starodum to the images of "exemplary landowners" in the second volume of Gogol's Dead Souls, rural "men of affairs" increasingly dominate the space of classical Russian prose and poetry. This problematic is especially salient in the stories and novels of Turgenev and Goncharov. These examples dispel the until recently firmly entrenched myth that the Russian classics are populated exclusively by "dead souls" and "superfluous people." Tolstoy too successfully continues the tradition of "positive affair" in Russia. 


\section{Nikolsky S.A.}

Nevertheless, the central theme that Tolstoy develops in his second novel is that of love in the form of passion - an anomalous form that goes beyond the bounds of the rational. Tolstoy examines the phenomenon of passionate love under conditions that would appear to make the existence of this feeling impossible. And for this reason alone it is akin to the feeling investigated by Shakespeare in Romeo and Juliet, Othello, or King Lear.

In War and Peace Tolstoy merely touches on the phenomenon of passion. While Natasha in War and Peace is carried away by an evil external power, Anna can do nothing with her own heart, captive to passion. Within the couple constituted by Anna and Vronsky, it is precisely Anna who is the source of passion. Throughout the novel we sense that Vronsky merely resonates to the stormily rising passion of the heroine. Anna needs Vronsky's constant physical presence; she is concerned to ensure that he should have no interests or relationships that are independent of her. Even when they are living quietly together in the countryside, any absence of Vronsky on business leads to tension, suspicion, and conflict.

It is obvious that in order to survive and to withstand hostile circumstances passionate love must be extraordinarily strong and keen to the point of morbidity. In an unhealthy environment, the very nature of people and their experience do not allow love to be vital and strong but harmonious (that is, not to cross the limits beyond which self-destruction begins). Indeed, in order to exist at all in an unhealthy environment, feeling must be hardened in confrontation. In other words: first, it must overcome hostile forces, and, second, it must not be destroyed after inevitable deformation in the struggle against these forces.

Applied to Tolstoy's heroine, this means that Anna's growing passion reaches the point of self-destruction not only because self-destruction takes root in her heart, but also for external reasons: her lover does not know how to live a family life; her abandoned husband is a machine, prospering in his government career and only once displaying human feelings; her brother is an egoistic sybarite, incapable of empathy; and according to the concepts accepted by high society secret marital infidelity (as in the case of Princess Betsy) is the norm, while Anna's striving openly to uphold her right to live by love is pathological. Anna's tragedy seems to be even deeper than the author initially tries to portray it when, as Zverev and Tunimanov observe, he sets himself the task of "making this woman only pitiable and not guilty"29. For if we compare the clash of the non-

29 Zverev and Tunimanov 2007, p. 295. living Anna with the world and the analogous clash of Natasha Rostova, the difference is enormous. Natasha is merely a victim, a weak being who has fallen into the clutches of a corpse and been infected by its poison but who, thanks to circumstances, is happily saved and gradually restored to health. Anna is something else. She is in fact an adulteress who from the start has made use of the opportunities and power of "society": thanks to her marriage of convenience with Karenin, she fully belongs to high society. Let us recall that until Anna takes the decisive step - confessing to her husband that she has committed adultery, bringing her love for Vronsky into the open - she does not go beyond the bounds of generally accepted behavior.

But Anna resolves to act openly. What does she betray? What relations does she destroy? What boundaries does she cross? Undoubtedly, her husband is placed in a humiliating position and truly suffers from the undeserved insult. He has never deceived Anna, never tried to appear better than he really is (due to his natural limitations, the idea would simply not have occurred to him). It is Anna who has broken the contract tacitly concluded between them. So Anna's hatred for her husband, albeit understandable, is unjust. In her husband Anna hates her own past, her deal with "society."

It is another matter - and this is revealed in one of the novel's great scenes, where Karenin forgives Vronsky and his wife at the moment when she is almost dying after giving birth - that Anna's husband suddenly shows himself capable of rising above the false standards of "society" and finds within himself the strength to turn his conviction into action. "The emotional distress of Aleksei Aleksandrovich [Karenin] grew more and more intense and had now reached a point at which he no longer fought against it; he suddenly felt that what he had regarded as emotional distress was, on the contrary, a blissful spiritual state that had suddenly given him a new happiness that he had never felt before. It did not occur to him that the Christian law that he had always wanted to follow told him to forgive and love his enemies; but a joyous feeling of love and forgiveness for his enemies filled his soul" ${ }^{\prime 30}$.

In this scene Tolstoy reveals to us a great truth concerning the nature of passion. Passion is healed by forgiveness and death. Shakespeare says the same thing: the war between the Montagues and the Capulets dies down with the death of Romeo and Juliet; Othello's passion dies with the death of Desdemona. And, obviously, there exists no other means of ridding oneself of passion.

30 Tolstoi 1981, pp. 52-53. 


\section{Philosophy}

Avoiding being drawn into the developmental logic of passion, Karenin repudiates his Christian action, which is equivalent to a rebellion against society, and returns to adherence to the customary false conventions. His stance - to forgive his wife and even her loverwould, of course, be ridiculed by high society. Aleksei Aleksandrovich lacks the strength for such a courageous decision. It would be akin to passion, although of a different kind. But Karenin is a man without passions. And soon he decides to make no concession to Anna in anything, not to give her a divorce, to estrange their son from his mother.

Analyzing the nature of passion and calling his other characters to his aid, Tolstoy leads us into a realm bordering on passion - the realm of strong and authentic love. He does this in two ways: positively, by conveying the experiences of Levin as he conceives the intention of making a proposal to Kitty, and negatively, by telling us about Vronsky. Levin, as we recall, having arrived in Moscow, sets off for a skating rink where Kitty is amusing herself. He does not resolve to approach Kitty. He is held back by everything, even her smile. Kitty guesses that Levin loves her, but gives preference to Vronsky. However, there is an important difference in her attitude toward the two men - and not in favor of Aleksei Kirillovich [Vronsky]: she senses "something false" in him ${ }^{31}$. But this falsity is of the kind that high society recognizes and calls "magnificence." We find a classically precise appraisal of the two chief love relationships - that between Anna and Vronsky and that between Kitty and Levin - in Vladimir Nabokov. According to Nabokov, the first union is built solely on physical love and is therefore doomed. Levin's marriage, by contrast, "is based on a metaphysical and not a physical understanding of love, on readiness for self-sacrifice, on mutual respect"32. For myself I add that behind this spiritually rich and personality-filled metaphysic there invisibly lurk, of course, the values of home and family. In the Russian world outlook, as the classics of Russian literature before Tolstoy had already repeatedly demonstrated, a home is not just a place of shared warmth. It is a place where kindred bodies intermingle in harmony and souls resound in unison. Otherwise there is no true metaphysical Home. And for Tolstoy Home is the one that Levin and Kitty build - a Home of love and shared lofty spirit. Anna has no Home; for her a Home is altogether impossible.

Having given herself up to passion, Anna becomes another person and starts to see many things in a dif-

\footnotetext{
$31 \quad$ Tolstoi 1981, p. 57.
}

$32 \quad$ Nabokov 1996, p. 57. ferent light. Even her beloved son Seryozha seems to her worse than she imagined him when they were apart. But Vronsky is a being of quite another kind. Compared to Anna, he is less refined, developed, and profound. "In his St. Petersburg world, all people were divided into two diametrically opposite sorts. There was the inferior sort: vulgar, stupid, and - above all ridiculous people who believe that one man should live with the one woman to whom he is married, that a young girl should be innocent, a woman modest, and a man manly, restrained, and firm, that you should bring up your children, earn your bread, and pay your debts and various other idiocies in a similar vein. These were the old-fashioned and ridiculous sort of people. But there was another sort of people, real people, to which they all belonged. For them the important thing was to be elegant, beautiful, generous, bold, and cheerful, to abandon oneself to any passion without embarrassment, and to laugh at all the others" ${ }^{\prime 3}$. And there follows a clear definition of emotions: genuine passion in Anna and at first a likeness of passion (sanctioned by high society, as it were, like Stiva's flirtatiousness) in Vronsky. It is impossible to be sure whether Vronsky is inherently capable of going beyond the bounds of flirtatiousness or whether he is enabled to do so by the strength of Anna's passion, but soon his attitude toward his liaison with Anna changes. Vronsky does not realize that the growing dissatisfaction within society, apart from the characteristic propensity of any social organism to react negatively to violations of the established order of things, is also fed by indignation at their indifference to society. After all, both Vronsky and Anna - especially Anna, with the history of her marriage and move from the provincial backwoods into the highest society - were, and were rightfully regarded as, members of society, to which they should be grateful and obedient. However, Vronsky's inability to perceive fully all that his affair with Anna has put in motion does not prevent him from groping intuitively toward a conclusion that is loyal to Anna's passion: "For the first time the thought clearly occurred to him that it was necessary to end this lie, and the sooner the better. 'She and I should abandon everything and hide away somewhere, alone with our love,' he said to himself" ${ }^{\prime 3}$. Indeed, a reclusive life, far removed from the world - for example, as a landowner in the provincialbackwoods is a real way out, or in any case a possible alternative to the growing ostracism.

\footnotetext{
33 Tolstoi 1981, p. 129

34 ibid., p. 129.
} 


\section{Nikolsky S.A.}

If we try to view Vronsky's behavior not through the eyes of passion but in what is called an impartial manner, then we shall hardly find cause for words of reproach. Vronsky is trying to be a normal person who loves Anna. It is Anna who is carried away by the stream and loses self-control. Tolstoy indirectly gives us to understand that this is the case by various means, including an attitude that is very strange for a woman capable of love - her indifference toward her daughter. It is as though her daughter - the possibility of a future life, even together with her beloved, her daughter's father, Vronsky - does not exist for Anna. She is wholly in the power of the feeling that is consuming her; it is so strong that it appears to have halted her further development and closed off the future to her. Perhaps this reveals another feature of passion - it can develop only through and on the basis of the feelings, consciousness, and experience that the person possessed at the moment of being overwhelmed by the passion. The person in the grip of passion falls into a closed circle of constantly reliving the experience and fullness of consciousness that were in him at the moment when the passion began. There is only one way out of this state - death.

The incapacity for further development is itself one of the forms of death; therefore, all who are captured by passion become tragic characters, and their physical death is merely the materialization of the earlier death of their consciousness and feelings or - to resort to terms from the Russian literary-philosophical tradition - of their minds and hearts. Let us recall, for instance, how Goncharov's character, Ilya Ilyich Oblomov $^{35}$, spends the last years of his life married to the widow [Agaf' ia] Pshenitsyna: he seems to ossify, as is seen with special clarity when he is visited by Stolz. In the case of Oblomov, passion kills Ilya Ilyich (or, which is the same thing, Ilya Ilyich kills within himself his passionate love for Ol ga [Il inskaia]) instantaneously, although the burial rite is postponed.

In reading and interpreting a work of literature, it may be possible to "complete" certain thoughts and work through deep semantic implications that are logically inferred by the reader or left open by the author, although not always drawn out by him and therefore not manifest in the text. This, indeed, is one of the distinguishing features of a truly great literary-philosophical works, and Anna Karenina is one of them.

In support of the observation that the meaning of a text may be broader than its verbal expression, let

35 A main character of the celebrated novel by Alexander Goncharov, Oblomov (1858). - Ed. me cite these reflections of Iosif Brodsky: "The writer of a poem writes it because his tongue prompts him or simply dictates the next line. When he starts a poem, the poet does not, as a rule, know how it will end, and sometimes he is very surprised at the result, for often it is better than he anticipated, often his thought goes further than he expected"36. As is well known, Tolstoy thought of writing a novel about "family thought" and intended to give it a rather ironical tone (its original title was A Fine Old Girl [Molodets baba]) and talk in it about "love affairs of the nobility." However, as he became more and more deeply immersed in the problem of passionate love, Tolstoy found himself creating something quite different, thereby confirming the "demonic reputation" (Brodsky) of literature. He ended up with a "poem of passion." And as such it "does indeed surpass anything created by Russian authors before Tolstoy" ${ }^{37}$.

In order to show how abnormal Anna is in her subordination to passion, Tolstoy brings his heroine face to face with Levin. Here is how this sequence unfolds. Together with Stiva, Levin visits Anna and makes her acquaintance. And right away he is struck by the number of merits that he sees in this pitiable woman. "As well as being intelligent, graceful, and beautiful, she was truthful. She did not want to conceal from him how very grave her situation was." When Stiva asks what sort of impression Anna made on him, Levin replies: "An extraordinary woman! Not so much intelligent as astonishingly warm-hearted. I feel terribly sorry for her!"38.

However, Tolstoy immediately observes: but he [Levin] sensed that in the "tender pity" that he felt for Anna there was "something else." And for Tolstoy, constructing his ideal type of the Russian world outlook, this "something else" means passion as a result of the pernicious influence of the city, of a person living outside of nature and the people, solely for the sake of carnal pleasures. Living in the city, the "natural" and "normal" person Levin "goes crazy." He understands that in the countryside he would never engage in the pursuits that he follows in Moscow, for these are just talking, eating, and drinking. He understands that he is living "an aimless, muddled life - moreover, a life beyond his means." And an abnormal life gives rise to abnormal human relations. One of the reasons that maternal feeling for her daughter does not awaken within Anna is that - in accordance with the custom, above all, among city ladies - she does not breastfeed the child herself

\footnotetext{
36 Brodskii 1997, p. 16.

37 Zverev and Tunimanov 2007, p. 57.

38 Tolstoi 1981, pp. 90-91.
} 


\section{Philosophy}

but entrusts this task to a wet nurse. The abnormal and unnatural life of the city does not allow Anna to give up the "relations of struggle" that have developed between Vronsky and herself - struggle for his freedom and against her social position of de facto serfdom.

The denouement of the novel approaches. The "evil spirit" that possesses Anna in the city again gains the upper hand. "And death, as the sole means of restoring love for her in his heart, punishing him, and winning victory in the war that the evil spirit lodged in her heart was waging with him, clearly and vividly appeared before her" ${ }^{39}$. Anna settles her accounts with life: "We all hate one another." "I have never hated anyone like I hate this man!" - she thinks regarding Vronsky. The terrible truth of her ruling passion reveals itself to her: "If only I could be something besides a lover, passionately loving only his caresses! But I cannot and do not want to be anything else." She remembers her son: "What about Seryozha? I also thought that I loved him, and I was moved by his tenderness. But I lived without him, I exchanged him for another love, and I did not complain about this exchange for so long as I was satisfied with my new love" 40 .

Everything and everyone around her seem "ugly and dismembered." The latter word is portentous, signifying transition to the approaching denouement: after a certain time Anna's body will indeed be dismembered and, anticipating this horror, she subconsciously starts to grow accustomed to what is happening to her and perceive it as almost routine. In other words, it is what she constantly sees and has got used to, and for this reason it can no longer terrify her.

But it is impossible to get used to this. And she nonetheless makes a last attempt to return to life in her instinctive motion to pull her body back from the speeding train under which she has only just thrown it. But it is too late. "And the candle by which she was reading the book - a book filled with anxiety, deceit, woe, and evil - flared brighter than ever, lit up for her all that was previously hidden in gloom, flickered, started to dim, and went out forever" ${ }^{\prime \prime}$. Anna is no more. Passion has extinguished the candle that was her life.

Tolstoy tries to examine both sides of the interaction between his heroes and an external world that is wrongly ordered and therefore hostile to them. But while in War and Peace he touches only lightly on the nature of the society in which Prince Andrei, Pierre, and Natasha live, and in Anna Karenina considers the prob-

\footnotetext{
39 Tolstoi 1981, p. 345.

$40 \quad$ Ibid., p. 359.

$41 \quad$ Ibid., p. 364.
}

lem more thoroughly but of necessity in local terms, in Resurrection society - together with the main character of the novel, Prince Dmitrii Ivanovich Nekhliudov is the chief object of the author's analysis.

What interests Tolstoy in Nekhliudov is not so much his external connections (as in the case of Konstantin Levin and his agrarian business pursuits) as his own "change-transformation-resurrection." And while in Anna Karenina Tolstoy describes the path of descent to death, in Resurrection the vector of movement, represented by Maslova and Nekhliudov, points upward: through repentance to moral rebirth.

It is of interest to examine Tolstoy's novel Resurrection from the vantage point of working out the system of the Russian world outlook also because for the first time in Russian literature the central focus of analysis is business not as economic practice but as a man making himself. As a result, the Russian world outlook is enriched with an important and henceforth ineradicable aspect: the reflection of a man concerned with his own transformation.

Nekhliudov appears in the plot of the novel in two images. The first pertains to the moment of his moral fall, the second to a time ten years later, when he happens to meet Katya [Maslova] at a court trial. In the first image, Nekhliudov is "a depraved, refined egoist who thinks only of his own enjoyment" and "looks upon his healthy strong animal ' $I$ ' as his real self" Everything is simple for him: there are no enigmas; there is no intercourse with nature or with thinking and feeling people. For Nekhliudov a woman is just "one of the best means toward an already experienced enjoyment." According to Tolstoy, he lives in this way because he does not "believe in himself": he does not decide any question in favor of his "spiritual I" but, on the contrary, "believes in others" and does everything to please his "animal 'I'"43.

The degradation of the young Prince Nekhliudov, which begins after he moves from the countryside to St. Petersburg, is completed by his entry into military service. It is important to note that in Resurrection, written during his declining years, as in War and Peace, Tolstoy repeats one of his favorite ideas - the morally harmful nature of military service as a fundamental social institution. "Military life in general depraves men. It places them in conditions of complete idleness - that is, absence of all rational and useful work; frees them of their

\footnotetext{
42 Tolstoi 1983, pp. 52-53.

43 Interesting reflections along these lines (in the spirit of the Orthodox-Christian tradition) can be found in the book by Mardov (Mardov 2005).
} 


\section{Nikolsky S.A.}

common human duties, which it replaces by merely conventional duties to the honor of the regiment, the uniform, the flag; and, while giving them on the one hand absolute power over other men, also puts them into conditions of servile obedience to those of higher rank than themselves"44. And an idle life has an especially corrupting influence on military men because "should a civilian lead such a life he cannot help being ashamed of it in the depth of his soul. A military man, on the contrary, thinks that this is how things should be; they boast and are proud of such a life, especially at time of war" ${ }^{\prime 4}$. Nekhliudov's egoism, self-love, and indifference toward others reach their apogee in his seduction of Katya. Tolstoy emphasizes the complete unsuitability of these "values" for his postulated system of the Russian world outlook by comparing them with an invariable dominant - nature. [Later] reflecting upon his sin, Nekhliudov also recalls on what a terrible night it was committed: the ice breaking up on the river, the storm, and especially "the waning, upturned moon that rose before morning and dimly lit up something black and weird" 46 .

The novel does not lay bare the causes that compelled Nekhliudov to begin moving away from his "animal 'I'" toward his "spiritual 'I"' - it all happens as though by itself at the moment when Nekhliudov recognizes Katya Maslova among the defendants. Tolstoy simply registers the new state in which Dmitrii Ivanovich "in the depth of his soul ...already felt the cruelty, foulness, and baseness, not only of this particular action of his but of his whole idle, depraved, cruel, and self-satisfied life; and that dreadful veil which had in some unaccountable manner hidden from him this sin of his and the whole of his subsequent life was beginning to shake, and he caught glimpses of what was covered by that veil"47. This is the same cry - only a "silent" cry - of the soul that has caught sight, as in a mirror, of itself dead.

As he achieves "resurrection," Nekhliudov discovers with horror that he previously lived in a city of the dead. Especially symbolic in this connection is the episode in which Nekhliudov finds himself in the house where his mother lived and died. As she dried up like a mummy before death, the woman lay in a room beside a portrait that depicted her as a half-naked beauty. This majestic portrait reminds Nekhliudov of the high soci-

\footnotetext{
$44 \quad$ Ibid., p. 54.

$45 \quad$ Ibid., p. 55.

46 Ibid., p. 73.

47 Ibid., p. 83.
}

ety in which until recently he has lived and although dead felt himself to be alive. By means of this association, Tolstoy again takes us back to the theme of the "nonliving-artificial" and "living-natural." In Resurrection, however, this theme acquires a new aspect.

As we recall, Nekhliudov, wishing to redeem his guilt before Katya, decides from the very start that he must marry her: "This morning he was especially moved by the thought of sacrificing everything and marrying her for the sake of moral satisfaction" ${ }^{\prime 2}$. What is more salient in this absurd but moving thought pride in his own readiness for "sacrifice" or the habits of the landlord advocating serfdom, albeit a moral one, who does as he "wishes"? In any case, he does not relate to Katia as a free person, as a woman whom he cannot presume to marry without regard to her wishes. He is still in thrall to his self-willed "animal 'I'," clothed as it may be in decorous attire.

Nekhliudov's "cleansing of the soul," as Tolstoy calls it, takes place as the hero journeys through the worlds of the "living" and the "dead." Here the world of the "living" - the world of prisoners - has attributes of the subterranean world of the dead; conversely, the world of the "dead" on the surface seems alive. In essence, "high society" and "the prison" are ordered in almost identical fashion. In both places, falsehood lords it over truth, force over kindness and justice, the base over the lofty. And only the person (it does not matter in which world he finds himself) who has begun to believe that he is the image and likeness of God and to act accordingly changes this nonliving world.

Pondering over how it has come to pass that "it is no longer obligatory to treat human beings as human beings," Tolstoy answers through the words of Nekhliudov: the whole problem is that people "recognize as law what is not law and fail to recognize as law the eternal, unchangeable, peremptory law inscribed in people's hearts by God Himself. ...Only allow yourself to deal with people without love, .... and there is no limit to your cruelty and savagery in relation to others ...nor is there any limit to your own suffering"49.

As a special case, the personal contact of Natasha Rostova or Anna Karenina with the world of the "nonliving" acquires in the concluding part of Resurrection the character of a generalization, a verdict on the entire social order as dead flesh: "Of all the people living at liberty, the courts and administration have selected the strongest, the most highly strung, the most ardent, excitable, and gifted, those who are less cunning and cau-

48 Ibid., p. 123.

49 Ibid., pp. 362-63. 


\section{Philosophy}

tious than others, and these people, who are in no way more guilty or more dangerous to society than those who have remained at liberty, have been locked up in prisons, in holding centers for transported prisoners, and at forced labor" (ibid., p. 423). And further on: "All these appeared to be institutions specially designed to produce such perversion and vice, concentrated to the highest degree, as could not be achieved under any other conditions, in order then to spread this concentrated vice and perversion as widely as possible throughout the nation" (ibid., p. 424).

Thus, starting with a primary focus on the lives and fates of individual characters, Tolstoy ascends from one work or novel to the next until he reaches generalizations concerning the nature of the entire society of his day. In the process, the panorama of the Russian world outlook that he creates becomes increasingly substantive and capacious, and its perspective increasingly profound.

\section{Notes:}

1. Hunting, Lifshits argues, is not an incidental theme in nineteenth-century Russian literature. It entered literature together with the focus on nature and peasant life as fundamental supports of the national world outlook. In Turgenev, for example, the nobleman-hunter in his Notes of a Hunter [Zapiski okhotnika] is a wanderer away from his home and country estate, and free of obligations to them. Those who happen to join him in his free hunter's life, for a certain time or forever, are torn away from the soil and neglect their age-old occupations.

2. Tolstoy himself finally resolves the struggle against the fear of death by departing from his habitual but now alien life environment. And this departure turns out to be a departure into death.

3. Interesting reflections along these lines (in the spirit of the Orthodox-Christian tradition) can be found in the book by Mardov (Mardov 2005).

\section{References:}

1. Bakhtin, M.M. Sobr. soch. v 7-mi t. Vol.

2. Moscow: Russkie slovari, 2000. 2. Brodskii, I. Sochineniia Iosifa Brodskogo. St. Petersburg: MCMXVIII, 1997.

3. Kritika 60-kh godov XIX veka. Moscow: Astrel, 2003.

4. Lifshits, M.A. Mifologiia drevniaia i sovremennaia. Moscow: Iskusstvo, 1979.

5. Mardov, I.B. Lev Tolstoi. Drama i velichie liubvi. Moscow: Progress-Traditsiia, 2005.

6. Nabokov, V. Lektsiipo russkoi literature. Moscow: Nezavisimaia gazeta, 1996.

7. Strakhov, P.P. «O 'Voine i mire'.» In Biblioteka russkoi kritiki, 2003.

8. Tolstoi, L.N. Sobr. soch. v 22-kh t. Vols. 1-3. Moscow: GIKhL, 1978.

9. Tolstoi, L.N. Sobr. soch. v 22-kh t. Vol. 4. Moscow: GIKhL, 1979.

10. Tolstoi, L.N. Sobr. soch. v 22-kh t. Vol. 8. Moscow: GIKhL, 1981.

11. Tolstoi, L.N. Sobr. soch. v 22-kh t. Vol. 13. Moscow: GIKhL, 1983.

12. Zverev, A.M., and V.A. Tunimanov. Lev Tolstoi. [In serial: Zhizn 'Zamechatelnykh Liudei]. Moscow: Molodaia gvardiia, 2007. 